\title{
Determination of Rocuronium bromide by hydrophilic interaction liquid chromatography (HILIC)
}

\author{
Natalija Nakov ${ }^{1 *}$, Rumenka Petkovska ${ }^{1}$, Liljana Ugrinova ${ }^{2}$, Suzana Trajkovic-Jolevska ${ }^{1}$, \\ Aneta Dimitrovska ${ }^{1}$

\begin{abstract}
'Institute of Applied Chemistry and Pharmaceutical Analysis, Faculty of Pharmacy, University "Ss Cyril and Methodius", Vodnjanska 17, Skopje, Macedonia

${ }^{2}$ Center of drug quality control, Faculty of Pharmacy, University "Ss Cyril and Methodius", Vodnjanska 17, Skopje,
\end{abstract} \\ Macedonia
}

Received: November 2011; Accepted: January 2012

\begin{abstract}
A new method involving hydrophilic interaction liquid chromatography (HILIC) has been developed for determination of rocuronium bromide in presents of its main impurities (impurity A and impurity C), which are also its main degradation products, in solution for injection. The influence of the critical chromatographic parameters such as content of acetonitrile in the mobile phase, ionic strength and $\mathrm{pH}$ value of the buffer used in the mobile phase were investigated using the Design of experiments approach (DoE). The mechanism of retention of rocuronium bromide on bare silica column was also investigated. Optimal chromatographic conditions were obtained using mixture of acetonitrile and ammonium formate $(107.5 \mathrm{mM}, \mathrm{pH} 7.0)$ in ratio $90: 10$ as a mobile phase. The validation results have shown that the method is suitable for determination of rocuronium bromid in solution for injection.
\end{abstract}

Keywords: rocuronium bromide, HILIC, Design of experiments, retention mechanism

\section{Introduction}

Rocuronium bromide (Roc) is widely used as aminosteroidal non-depolarizing neuromuscular blocking agent with rapid onset of action and intermediate duration of the blocking effect. Since 1994 it is avaible as a solution dosage form intended for intravenous or intramuscular injection (Blazewich et al., 2007; Gao et al., 2001). Rocuronium bromide is a polar drug with octanol/water partition coefficient of 0.5 (Moffat et al., 2004). This compound has eight identified impurities, labeled from A to H. Impurity A (N-desallylrocuronium) and impurity $\mathrm{C}$ (17-desacetylrocuronium) (Fig. 1) are not only main metabolite products,

\footnotetext{
* tel: +38923126032 ext.123;

fax: +38923123054

natalijan@ff.ukim.edu.mk
}

but they are also main degradation products of rocuronium (Blazewich et al., 2007).

The analytical techniques for determination of rocuronium bromide and its main metabolites in biological samples presented in the literature included liquid chromatography-mass spectrometry (Cirimele et al., 2003; GutteckAmstel and Rentsch, 2000; Farenc et al., 2001; FuchsBuder et al., 2004; Sayer et al., 2004) and gas chromatography with mass spectrometry (Gao et al., 2001). There is only one published method for determination of rocuronium and its impurities in pharmaceutical preparation, which includes liquid chromatography with electrochemical detection (Blazewich et al., 2007). Ph.Eur 7.0 recommends determination of assay of rocuronium bromide using titration and its related substances by ion-pair reversephase liquid chromatography (European Pharmacopeia $7.0,2010)$. USP-32 recommends determination of rocuronium bromide substance and its related compounds by re- 
verse-phase liquid chromatography with ion-pair mobile phase (United States Pharmacopeia 32, 2009). Generally, ion-pair chromatography methods have number of disadvantages such as long equilibration time (in this case 4 hours), disturbance of equilibration by injection and ireversed change of the stationary phase caused by the use of ion-pair reagent (Dejaegher and Vander Heyden, 2010; Hemstrom and Irgum, 2006; Snyder et al., 2010).

Hydrophilic Interaction Liquid Chromatography (HILIC) provides an alternative approach for effectively separation of polar compounds on polar stationary phases. This technique employs polar stationary phase (most often bare silica) with mobile phase containing small amount of water phase (at least $3 \%$ ) and large amount (60-97\%) of polar organic solvent (Dejaegher and Vander Heyden, 2010; Hemstrom and Irgum, 2006; McCalley, 2007, 2010a).

The aim of this work was to develop a HILIC method for quantitative determination of rocuronium bromide in the presents of its main impurities (impurity A and impurity $\mathrm{C}$ ) using the Design of Experiments approach (DoE). Generally it is accepted that the use of DoE affords the most convenient way to deal with optimization of methods since the traditional step-by-step approach involves a large number of independent runs.

The retention mechanism in HILIC is complex and partition mechanism may occur together with adsorption, ion exchange and even hydrophobic interaction under appropriate experimental conditions. In order to gain more insight into the HILIC mechanism, assessment was made to investigate the relative contribution of adsorption, partition and ion-exchange mechanism to the retention of rocuronium bromide on bare silica column.

\section{Experimental}

\subsection{Chromatographic conditions}

Separation was performed on Agilent Rapid Resolution HPLC System 1200 Series, using Purospher STAR Si (150 $\mathrm{x} 4,6 \mathrm{~mm}, 5 \mu \mathrm{m}$ partical size) with a mixture of ammonium formate $(107.5 \mathrm{mM}, \mathrm{pH} 7.0)$ and acetonitrile in ratio $90: 10(v / v, \%)$, with flow rate $2.0 \mathrm{ml} / \mathrm{min}$ at $30{ }^{\circ} \mathrm{C}$. The injection volume was $10 \mu 1$ and detection was carried out at $210 \mathrm{~nm}$.

\subsection{Design of Experiments}

Central Composite Face Centered (CCF) Design was used for method optimization. The MODE 8.0 software was used for generation and evaluation of the experimental design.

\subsection{Reference substances, reagents and chemicals}

Rocuronium bromide working standard was obtained from Hameln rds. Modra, Slovakia. Ammonium formate was supplied from Fluka, Switzerland; formic acid and acetonitrile (HPLC grade) by Merck, Germany, ammonium hydroxide solution (c.c. $25 \% \mathrm{NH}_{3}$ ) by Sigma-Aldrich, Germany. The reagents were analytical grade and water of HPLC grade was used.

\subsection{Standard and sample solution preparation}

Rocuronium bromide standard solution in concentration of $1 \mathrm{mg} / \mathrm{ml}$ was prepared. Test solution was prepared from Rocuronium bromide Kabi $10 \mathrm{mg} / \mathrm{ml}$ solution for injections in concentration of $1 \mathrm{mg} / \mathrm{ml}$. Mixture of acetonitrile and water in ratio 90:10 $(v / v, \%)$ was used as a solvent for standard and test solution. Standard solution of Roc in concentration $0.5 \mathrm{mg} / \mathrm{ml}$ was degradated for 1 hour in oven at $105{ }^{\circ} \mathrm{C}$ in order to obtain impurity A and impurity $\mathrm{C}$.

Five standard solutions were prepared for the calibration curve in the range of 0.5 to $1.5 \mathrm{mg} / \mathrm{ml}$ (from $50-150 \%$ of the working concentration). Another five standard solutions were prepared in concentration from 0.015 to 0.05 $\mathrm{mg} / \mathrm{ml}$ (from $1 \%$ to $5 \%$ of the working concentration) for determination of the limit of detection and limit of quantification of the method. The determination of accuracy of the method was done by method of standard additions, by adding known amounts of rocuronium bromide standard to the sample placebo at three concentrations $(80 \%, 100 \%$ and $120 \%$ ).

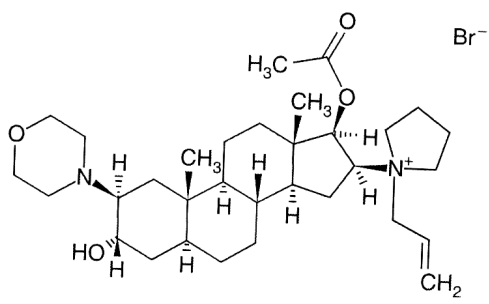

a)



b)

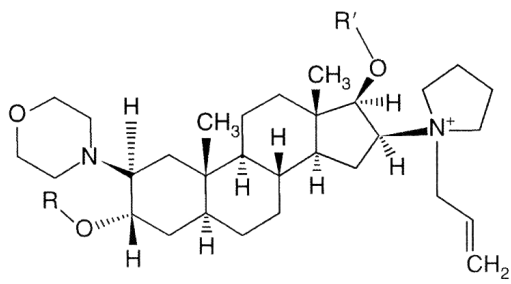

Fig. 1. Structure of: a) Rocuronium bromide, b) Impurity $\mathrm{A}(\mathrm{R}=\mathrm{CO}-\mathrm{CH} 3)$, c) Impurity $\mathrm{C}\left(\mathrm{R}=\mathrm{R}^{\prime}=\mathrm{H}\right)$ 


\section{Results and discussion}

\subsection{Optimization of chromatographic conditions}

The physico-chemical properties of rocuronium bromide and the previous knowledge about the critical chromatographic parameters in HILIC, were taking into consideration during the method development. The experimental design approach was chosen over the systematic approach, because it allowed simultaneous study of multiple variables (e.g. acetonitrile content, salt concentration etc.) which led to significant decrease in the number of experiments and also allowed to evaluate the factor interactions (Deming and Morgan, 1993; Dejaegher et al., 2008; Guo et al., 2007; Lewis et al., 1999).

The results obtained during the preliminary investigation, had shown that Roc and impurity $\mathrm{C}$ are co eluting, probably due to the similarity of their structures. Impurity A was well separated from the rocuronium and it eluted after the dead volume of the column. In order to obtain optimal resolution $(\mathrm{Rs}>1.5)$ between rocuronium and impurity $\mathrm{C}$ for short retention time, CCF design was chosen for the method development. The method development included investigation of the effect of three chromatographic parameters, at three different levels (Table 1).

The system response was estimated by the retention time of Roc and resolution between Roc and impurity C. Multiple linear regressions were used to estimate the coefficients of the model, representing the relationship between the response variables measured and the chromatographic factors studied. The regression coefficient plots (Fig. 2a and 2 b) consist of bars that correspond to the regression coefficients with the magnitude of the effects proportional to the regression coefficients.
The plot obtained for retention time (Fig. 2a), indicated that the content of acetonitrile had the largest influence. Increasing the percentage of acetonitrile in the mobile phase has increased the retention time of rocuronium. This behavior was expected, because increasing the content of acetonitrile reduces the polarity of the mobile phase and therefore resulting in longer retention time. The regression coefficients have shown that higher concentration of the buffer and higher values for $\mathrm{pH}$ value of the buffer, reduced the retention time of Roc. Larger concentration of counter ion (ammonium ion) in the buffer reduces the electrostatic interaction between the analyte and the surface silanol groups on silica column by competing with the analyte for these sites, resulting in reduced retention time. In order to define the optimum range of the investigated factors for retention time as chromatographic system response, a contour diagram of the retention time of Roc as a function of the content of acetonitrile in the mobile phase and ionic strength of the buffer was constructed (Fig. 3).

The contour diagram of retention time of Roc showed that increasing the content of acetonitrile in the mobile phase and reducing the $\mathrm{pH}$ value of the buffer, leaded to longer retention of rocuronium. The shortest retention time of rocuronium bromide was obtained at $\mathrm{pH} 7.0$ of the ammonium formate.

The influence of the content of acetonitrile in the mobile phase and $\mathrm{pH}$ value of the buffer on the resolution (Rs) between Roc and impurity C, as a second chromatographic response (Fig. 2b), was the same as for the retention time. The ionic strength of the buffer on this chromatographic response had opposite influence that on the retention time, so bigger values for resolution between the two peaks may be obtained by increasing the concentration of the buffer.

Table 1. Chromatographic parameters and its experimental range for method development

\begin{tabular}{llcc}
\hline \multicolumn{1}{c}{ Parameters } & Factor levels \\
& $(-)$ & $(0)$ & $(+)$ \\
\hline $\mathrm{x}_{1}$ content of acetonitrile in the mobile phase $(\%)$ & 70 & 80 & 90 \\
$\mathrm{x}_{2}$ ionic strength of the buffer $(\mathrm{mM})$ & 95 & 107.5 & 120 \\
$\mathrm{x}_{3}$ pH of the buffer & 4.0 & 5.5 & 7.0 \\
\hline
\end{tabular}

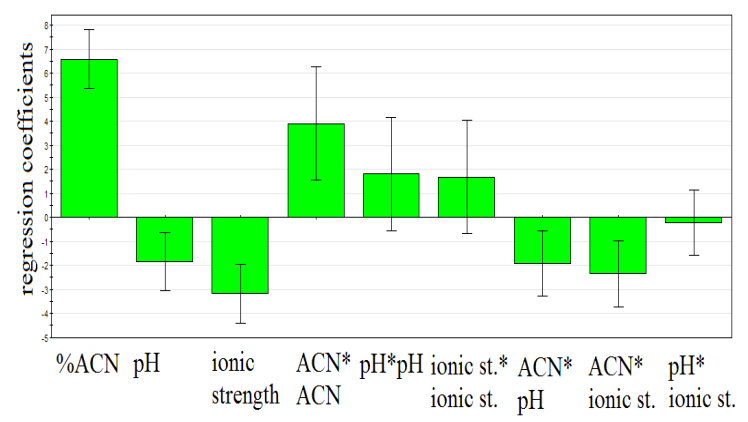

a

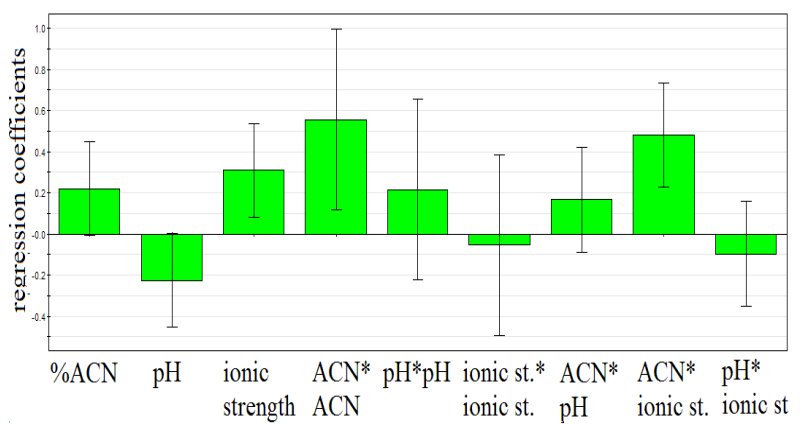

b

Fig. 2. Regression coefficient plot: a) retention time of Roc, b) resolution between Roc and impurity C, (\%ACN: acetonitrile content in the mobile phase, $\mathrm{pH}$ : $\mathrm{pH}$ value of the buffer, ionic st.: ionic strength of the buffer) 

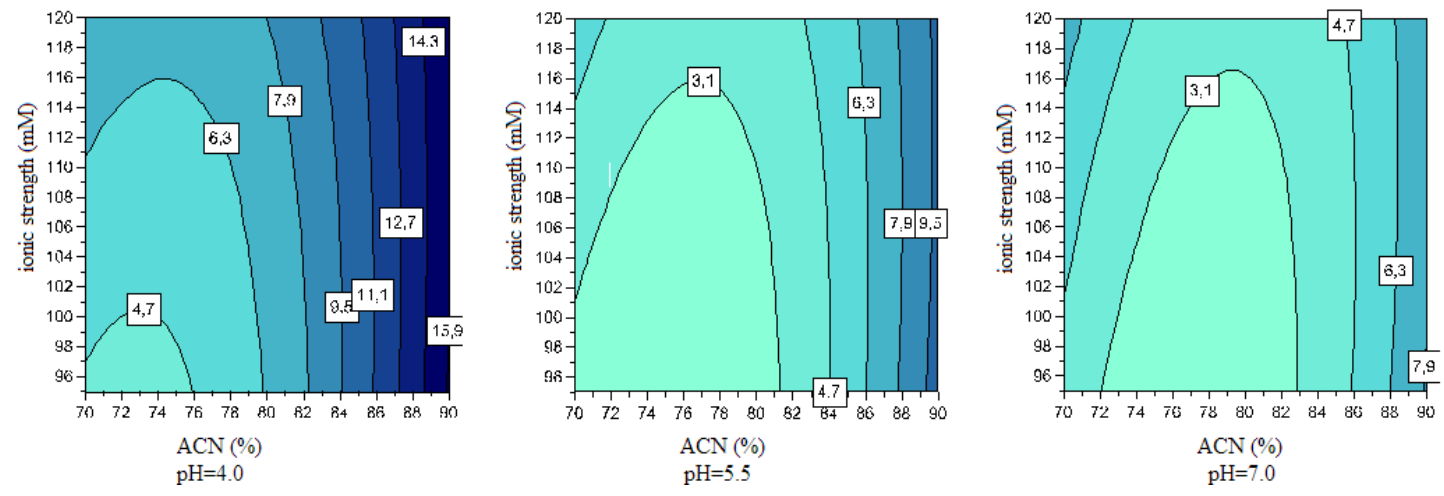

a

b

$\mathrm{c}$

Fig. 3. A contour diagram of retention time of Roc at: a) $\mathrm{pH}=4.0$, b) $\mathrm{pH}=5.5$, c) $\mathrm{pH}=7.0$

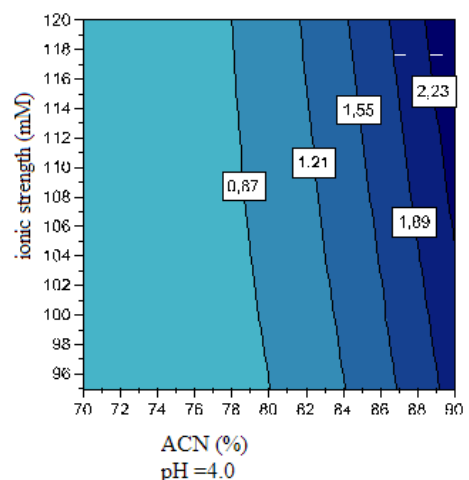

a

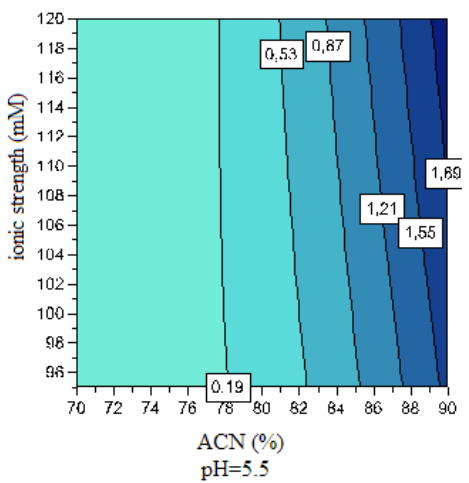

b

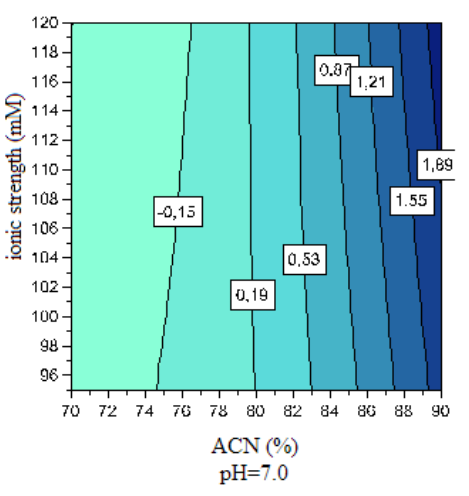

c

Fig. 4. A contour diagram for resolution between Roc and impurity $\mathrm{C}$ at: a) $\mathrm{pH}=4.0, \mathrm{~b}) \mathrm{pH}=5.5, \mathrm{c}) \mathrm{pH}=7.0$

The results obtained using Response Surface Methodology (Fig. 4) shown that resolution between Roc and impurity $\mathrm{C}$ was better at $\mathrm{pH} 4.0$ than at $\mathrm{pH}$ 7.0. The optimal resolution at $\mathrm{pH} 4.0$ may be obtained if the content of acetonitrile in the mobile phase is larger than $87 \%$. The optimal resolution at $\mathrm{pH} 7.0$ may be obtained if the content of acetonitrile in the mobile phase is larger than 89 $\%$, pointing that optimal value for resolution may be obtained for close values for the content of acetonitrile. The
$\mathrm{pH}$ value 7.0 was chosen as optimal considering the fact that the retention time of $\mathrm{Roc}$ at $\mathrm{pH} 4.0$ was significantly longer than at $\mathrm{pH} 7.0$ (15.9 min compared to $7.9 \mathrm{~min}$, respectively).

The optimal chromatographic condition, which corresponds to high values of Rs and short retention time, were obtained using mobile phase composition of acetonitrile and ammonium formate (107.5mM, $\mathrm{pH} 7.0)$ in ratio $90: 10$ $v / v$ (Fig. 5).

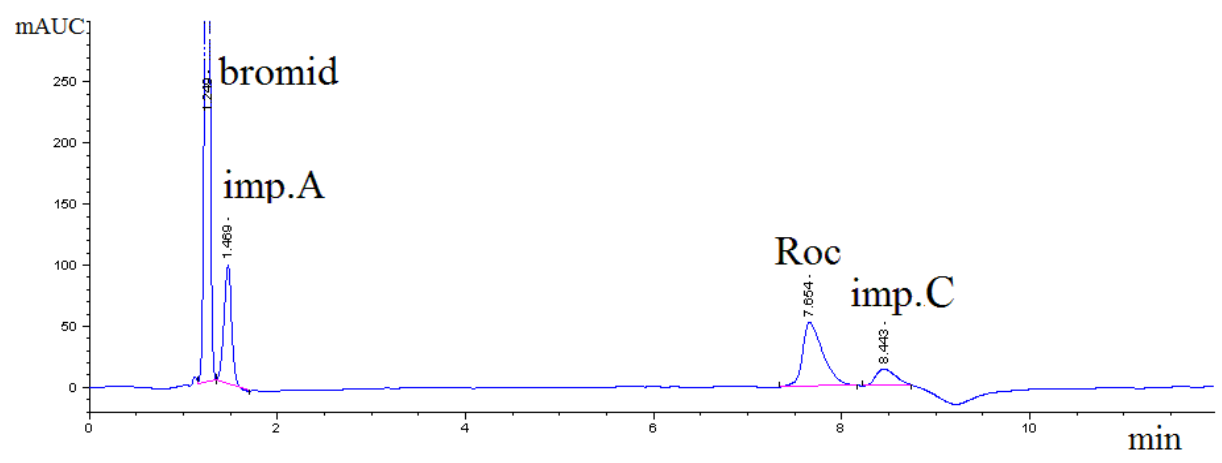

Fig. 5. Chromatogram of standard solution of Roc degradated for 1 hour at $105^{\circ} \mathrm{C}$ 


\subsection{Determination of contribution of partition, adsorption and ion exchange mechanism to the retention of rocuroni- um bromide on bare silica column}

In HILIC, the retention of the analyte is mediated by partitioning of analyte between a surface water layer and the bulk mobile phase, adsorption via processes such as hydrogen bonding and other dipole/dipole interactions and(or) ion-exchange interactions between ionized silanol groups and ionized analyte. Plotting the logarithm of the retention factor ( $\left.\mathrm{k}^{\prime}\right)$ versus volume fraction of the water phase (partition plot) or logarithm of mole fraction of the water phase (adsorption plot), should give an indication whether partitioning or adsorption is the dominant retention mechanism (Hemstrom and Irgum, 2006; Jandera, 2011; Karatapanis et al., 2011; Liu et al., 2008; Mccalley, 2010b). In this study, the percentage of the water phase (ammonium formate $20 \mathrm{mM}, \mathrm{pH} 7.0$ ) varied in the range from 10 to $30 \%$, and the obtained adsorption and partition plot were compared (Fig. 6a and 6b). The correlation coefficient obtained for the partition plot was higher than the correlation coefficient obtained for the adsorption plot (Table 2), pointing that partition is dominant retention mechanism for rocuronium.

Further information regarding the degree of electrostatic interaction involved in the retention can be obtained through estimation of the contribution of ion-exchange mechanism to the retention (Cox and Stout, 1987; Yang, 2003; Liu, 2009; McCalley, 2010b). In order to determinate the contribution of ion-exchange mechanism to retention, different concentrations $(10 \mathrm{mM}, 20 \mathrm{mM}, 50 \mathrm{mM}$ and $100 \mathrm{mM}$ ) of ammonium formate $(\mathrm{pH} 7.0)$ in mixture with acetonitrile (20:80, respectively) were used as mobile phase. Data obtained from regression analysis of the plot $\mathrm{k}$ ' vs. reciprocal values of concentration of ammonium formate in the buffer $\left(1 /\left[\mathrm{NH}_{4}^{+}\right]\right)$were used for calculation of the percent contribution of the ion exchange to retention of the rocuronium (Table 3).

The obtained results have shown that the ion-exchange mechanism has influence on the retention on rocuronium bromide and its contribution was bigger at lower counterion concentration ( $91 \%$ contribution of ion exchange at 10 $\mathrm{mM}$ concentration of the buffer, compared to $56 \%$ at 100 $\mathrm{mM})$.

\subsection{Validation of the method}

The method was validated according to the requirements of ICH (International Conference on Harmonization, 2005).

No interferences were observed due to the presents of the main impurities (impurity A and impurity $\mathrm{C}$ ) and the placebo components (sodium chloride and sodium acetate), so the method selectivity was confirmed (Fig. 5, Fig. 7 and Fig. 8). The validation results (Table 4 and Table 5) indicated that the method is linear, accurate, sensitive and precise.
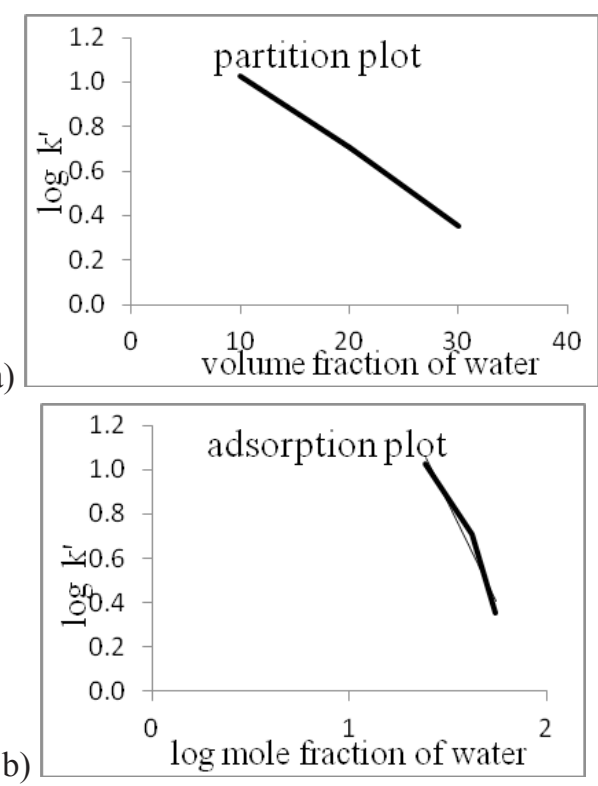

Fig. 6 Plot of $\log k^{\prime}$ versus: a) volume fraction of water (partition plot), b) log mole fraction of water (adsorption plot)

Table 2. Values for the intercept, slope and correlation coefficient obtained from partition and adsorption plot

\begin{tabular}{ccc}
\hline & Partition plot & Adsorption plot \\
\hline $\mathrm{a}$ & 1.3683 & 3.5682 \\
$\mathrm{~b}$ & -0.0336 & -1.8127 \\
$\mathrm{R}^{2}$ & 0.9994 & 0.9558 \\
\hline
\end{tabular}

Table 3. Contribution of ion exchange (\%) to retention of rocuronium bromide

\begin{tabular}{cc}
\hline \hline$\left[\mathrm{NH}_{4}^{+}\right](\mathrm{mM})$ & $\begin{array}{c}\text { Contribution of ion } \\
\text { exchange }(\%)\end{array}$ \\
\hline 10 & 91 \\
20 & 77 \\
50 & 71 \\
100 & 56 \\
\hline
\end{tabular}

The CCF experimental design was used for robustness testing of the method. Results obtained during the method optimization, indicated that optimal resolution may be obtain with in investigated range of ionic strength (95$120 \mathrm{mM}$ ) and $\mathrm{pH}$ value of the buffer, if the content of acetonitrile in the mobile phase is above $88 \%$. Therefore the influence of content of acetonitrile in the mobile phase and ionic strength of the buffer on the resolution between Roc and impurity $\mathrm{C}$ was investigated (Table 6). 


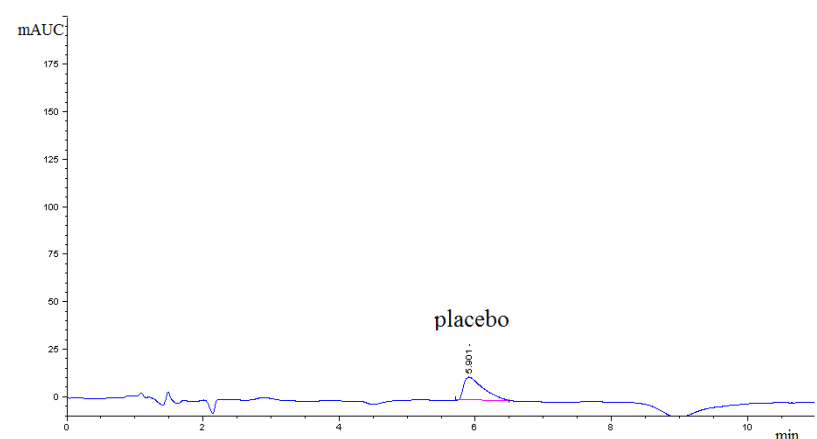

Fig. 7. Chromatogram of placebo solution

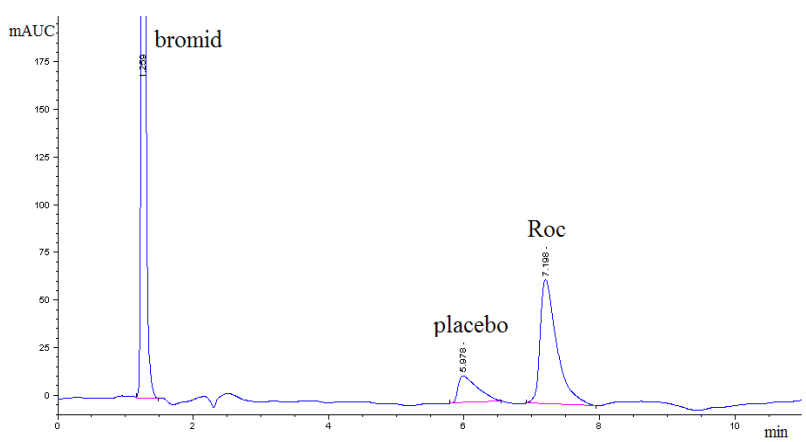

Fig. 8. Chromatogram of rocuronium bromide $10 \mathrm{mg} / \mathrm{ml}$ solution for injection

Table 4. Results obtained from testing different parameters during validation of the analytical method

\begin{tabular}{llc}
\hline \hline Validation parameter & \multicolumn{2}{l}{ Rocuronium bromide } \\
\hline Linearity & $0.5-1.5$ & $0.015-0.050$ \\
Concentration range $(\mathrm{mg} / \mathrm{ml})$ & 0.9998 & 0.9995 \\
Correlation coefficient & 71.209 & 17.586 \\
Intercept & 1030.3 & 2032.7 \\
Slope & & \\
LOD & 1 & \\
Concentration $(\mu \mathrm{g} / \mathrm{ml})$ & 3 & \\
LOQ & 1.05 & \\
$\quad$ Concentration $(\mu \mathrm{g} / \mathrm{ml})$ & & \\
Precision $(\mathrm{RSD} \%, \mathrm{n}=6)$ &
\end{tabular}

Table 5. Results obtained from testing of the accuracy of the method

\begin{tabular}{ccccc}
\hline \hline $\begin{array}{c}\text { Working concentration } \\
(\%)\end{array}$ & $\begin{array}{c}\text { Added } \\
(\mathrm{mg} / \mathrm{ml})\end{array}$ & $\begin{array}{c}\text { Determinated } \\
(\mathrm{mg} / \mathrm{ml})\end{array}$ & $\begin{array}{c}\text { RSD } \\
(\%)\end{array}$ & $\begin{array}{c}\text { Accuracy } \\
(\mathrm{P}=95 \%)\end{array}$ \\
\hline 80 & 0.79 & 0.783 & 0.58 & $99.10 \pm 1.4$ \\
100 & 1.03 & 1.024 & 0.52 & $99.47 \pm 1.27$ \\
120 & 1.18 & 1.198 & 0.26 & $101.57 \pm 0.66$ \\
\hline
\end{tabular}

Table 6. Chromatographic parameters (factors) and its experimental range during robustness testing

\begin{tabular}{clccc}
\hline \hline & Parameters & Factor levels & \\
& & $(-)$ & $(0)$ & $(+)$ \\
\hline x1 & Content of acetonitrile $(\%)$ & 88 & 90 & 92 \\
x2 & Ionic strength of the buffer $(\mathrm{mM})$ & 95 & 107.5 & 120 \\
\hline
\end{tabular}

The results had shown that small but deliberate changes in the chromatographic conditions $(89-91 \%$ acetonitrile and ionic strength of the buffer in the range of
$105-108 \mathrm{mM}$ ) did not affect the resolution between rocuronium bromid and impurity $\mathrm{C}$, so the method can be applied in routine work (Fig. 9). 


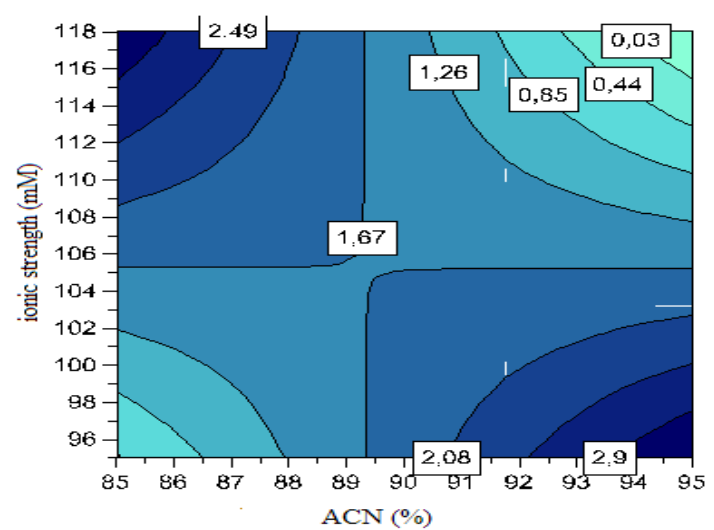

Fig. 9. A contour diagram of resolution between Roc and impurity $\mathrm{C}$

\section{Conclusion}

The proposed HILIC method enables a simple, rapid, accurate and selective quantitative determination of rocuronium bromide in solution for injection. The approach for optimization of the method using DoE represents an easily accomplishable approach for determination of the optimal HILIC condititions. The results obtained using the CCF design, confirmed that the content of the organic solvent and the ionic strength of the buffer are significant factors that affect the retention and separation in HILIC. Investigation of the retention mechanism has shown that the partition prevails over the adsorption as retention mechanism and the ion-exchange mechanism also has considerable contribution to the retention of rocuronium bromide.

\section{References}

Blazewich, A., Fijalek, Z., Warowna-Grzeskiewicz, M., Boruta, M., 2007. Simultaneus determination of rocuroniu and its eight impurities in pharmaceutical preparation using HPLC with amperometric detection. J. Chromatogr. A, 1149, 6672.

Cirimele, V., Villain, M., Pepin, G., Ludes, B., Kintz, P., 2003 Screening procedure for 8 quaternary nitrogen muscle relaxants in blood by HPLC-ESI-MS. J. Chromatogr. B 789, 107-113

Cox, G.B., Stout, R.W., 1987. Study of the retention mechanism for basic compound on silica under pseudo-reversed conditions. J. Chromatogr. 384, 315-336.

Dejaegher, B., Mangelings, D., Vander Heyden, Y., 2008. Method development for HILIC assay. J. Sep. Sci. 31, 1438-1448.

Dejaegher, B., Vander Heyden, Y., 2010. HILIC methods in pharmaceutical analysis. J. Sep. Sci. 33, 698-715.

Deming, S. N., Morgan, S. L., 1993. Experimental design: a chemometric approach. Elsevier Sci. Publishers R.V., Amsterdam.

European Pharmacopei 7.0, 2010. Consil of Europe, Strasbourg, France.

Farenc, C., Enjalbal, C., Sanchez, P., Bressolle, F., Audan, M., Martinez, J., Aubagna, J.-L., 2001. Quantitative determi- nation of rocuronium in human plasma by liquid chromatography-electrospray ionization mass spectrometry. J.Chromatogr.A 910, 61-67.

Fuchs-Buder, T., Strowitzki, M., Rentsch, K., Schreiber, J.U., Philipp-Osterman, S., Kleinschmidt, S., 2004. Concentration of rocuronium in cerebrospinal fluid of patients undergoing cerebral aneurysm clipping. Br. J. Anaesth. 92, 41-421.

Gao, L., Ramzan, I., Baker, B., 2001. Gas chromatographicmass spectrometric assay for rocuronium with potencial for quantifying its metabolite, 17-desacetylrocuronium, in human plasma. J. Chromatogr. B 757, 207-214.

Gutteck-Amstel. U., Rentsch. K.M., 2000. Quantification of the aminosteroidal non-depolarising neuromuscular bloking agents rocuronium and vecuronium in plasma with liquid chromatography-tandem mass spectroscopy. Clin. Chem. 46,1413

Guo, Y., Srinivasan, S., Gaiki, S., 2007. Investigating the effect of chromatographic conditions on retention of organic acids in HILIC using a design of experiments. Chromatographia 66, 223-229.

Hemstrom, P., Irgum, K., 2006. Hydrophilic interaction chromatography. J. Sep. Sci. 29, 1784-1821.

International Conference on Harmonization (ICH) on Techical Requirements for Registration of Pharmaceuticals for Human Use 2005. Guideline on Validation of Analitical Procedures: Text and Methodology Q2(R1), Harmonized Tripartite Guideline, ICH, Geneva, Switzerland.

Jandera, P., 2011. Stacionary and mobile phases in hydrophilic interaction chromatography: a review. Anal. Chim. Acta 692, $1-25$.

Karatapanis, A.E., Fiamegos, Y.C., Stalikas, C.D., 2011. A revisit to the retention mechanism of hydrophilic interaction liquid chromatography using model organic compounds. J. Chromatogr. A. 1218, 2871-2879.

Lewis, G.A., Mathieu, D., Phan-Tan-Luu, R., 1999. Pharmaceutical Experimental Design, Marcel Deker, New York, USA.

Liu, M., Chen, E.X., Ji, R., Semin, D., 2008. Stability-indicating hydrophilic interaction liquid chromatography method for highly polar and basic compounds. J. Chromatogr. A 1188, 255-263.

Liu, M., Ostovic, J., Chen, E.X., Cauchon, N., 2009. Hydrophilic interaction liquid chromatography with alcohol as a weak eluent. J. Chromatogr. A 1216, 2362-2370.

McCalley, D.V., 2007. Is hydrophilic interaction chromatography with silica columns a viable alternative to reverse-phase liquid chromatography for analysis of ionisable compounds. J. Chromatogr. A 1171, 46-55.

McCalley, D.V., 2010a. The chalenges of the analysis of basic compound by high performance liquid chromatography: Some possible approaches for improved separation. J. Chromatogr. A. 1217, 858-880.

Mccalley, D., 2010b. Study of selectivity, retention mechanism and performances of alternative silica based stationary phases for separation of ionised solutes in hydrophilic interaction chromatography. J. Chrom. A. 1217, 3408-3417.

Moffat, A.C., Osselton, M.D., Widdop, B. (Eds), 2004. Clarke's Analysis of Drugs and Poisons, Pharmaceutical Press, London.

Profiles of Drug Substances, Excipientes, and Related Methodology, 2010. 35 (6), 285-307, (ISSN 1871-5125)

Sayer, H., Quitnela, O., Marquet, P., Dupuy, J.-L., Gaulier, J.-M., Lachatre G., 2004. Identification and quantification of six non-depolarizing neuromuscular bloking agents by LC-MS

Макед. фарм. билт., 57 (1, 2) 17 - 24 (2011) 
in biological fluids. J.Anal.Toxicol. 28, 105.

Snyder, L.R., Kirkland, J.J., Dolan, J.W., 2010. Introduction to modern liquid chromatography 3th edition, John Wiley \& Sons,Inc., Hobeken, New Yersey, Canada.

United States Pharmacopeia 32 National Formulary 27, 2009. United States Pharmacopeial Convention, Rockville, MD.
Yang, X., Dai, J., Carr, W., 2003. Analysis and critical comparison of the reversed-phase and ion-exchange contributions to retention on polybutadiene coated zirconia and octadecyl silane bonded phases. J. Chromatogr. A 996, 13-31.

\title{
Определување на рокурониум бромид со примена на течна хроматографија со хидрофилна интеракција (HILIC)
}

\author{
Наталија Наков ${ }^{1 *}$, Руменка Петковска ${ }^{1}$, Лилјана Угринова², \\ Сузана Трајковиќ-Јолевска ${ }^{1}$, Анета Димитровска ${ }^{1}$
}

\author{
${ }^{1}$ Институт за примената хемија и фармацевтски анализи, Фармащевтски Факултет, Универзитет “Св.Кирил и \\ Методиј”, Водњанска 17, Скопје, Македонија \\ ${ }^{2}$ Центар за контрола на лекови, Фармацевтски Факултет, Универзитет “Св.Кирил и Методиј”, Водњанска 17, \\ Скопје, Македонија
}

Клучни зборови: рокурониум бромид, HILIC, дизајнирање на експерименти, механизам на ретенција

Развиен е нов метод за определување на рокурониум бромид во присуство на неговите главни онечистувања (онечистување А и онечистување С) кои воедно се и негови главни деградациони продукти во раствор за инјектирање со примена на течна хроматографија со хидрофилна интеракција (HILIC). Испитано е влијанието на клучните хроматографски параметри како што се удел на ацетонитрил во мобилната фаза, јонска јачина и рН вредност на пуферот кој влегува во состав на мобилната фаза со примена на дизајнирање на експерименти. Исто така направено е испитување на механизмот на ретенција на рокурониум бромид на необработена силика како стационарна фаза. Оптимални хроматографски услови се постигнати со примена на смеса на ацетонитрил и амониум формат (107,5 mM, pH 7.0) во однос 90:10 како мобилна фаза. Резултатите од валидацијата покажаа дека методот е соодветен за определување на рокурониум бромид во раствор за инјектирање. 